\title{
CAVEAT JURISCONSULTUS: WARRANTLESS ACCESS TO THE CLIENT RECORDS OF LEGAL PRACTITIONERS
}

\author{
Abraham Hamman \\ LLM LLD \\ Associate Professor, Department of Criminal \\ Justice and Procedure, Faculty of Law \\ University of the Western Cape \\ Raymond Koen \\ LLM PhD \\ Associate Professor, Department of Criminal \\ Justice and Procedure, Faculty of Law \\ University of the Western Cape
}

SUMMARY

A client legitimately regards almost all communications with his or her lawyer as confidential. However, there are circumstances in which client information is not protected under the attorney-client relationship and is accessible to certain third parties. In South Africa, the client records of legal practitioners are available to the anti-money laundering/combating the financing of terrorism (AML/CFT) agencies, which conduct inspections of law offices under the Financial Intelligence Centre Act 38 of 2001. In terms of a 2008 amendment, these inspections did not require a warrant.

In 2014, the South African Constitutional Court declared warrantless non-routine inspections unconstitutional. A legislative amendment of 2017 sought to restore the constitutionality of these inspections. However, neither the Constitutional Court nor the legislature addressed the issue of warrantless routine inspections. For the most part, then, AML/CFT inspections of the premises of legal practitioners need not be warrant-based. The danger here is that client records become ready evidentiary resources for the prosecution service.

The Canadian AML/CFT legislation also envisaged a mostly warrantless inspection regime. However, unlike South African legal practitioners, their Canadian counterparts launched a vigorous and sustained assault against the legislative efforts to erode the attorney-client relationship and the legal professional privilege. The Federation of Law Societies of Canada eventually secured exemption for its members from the compliance measures of the AML/CFT legislation. The Canadian experience should serve as an object lesson for the legal profession in South Africa. 


\section{$1 \quad$ INTRODUCTION}

The integrity of the legal profession depends on the integrity of the attorneyclient relationship. This is not a notional proposition. The day-to-day practice of law is rooted in the general legal guarantee that information imparted by a client to an attorney is protected by the legal professional privilege. Indeed, the client invariably perceives the attorney-client relationship as one governed by the seal of the confessional. Whereas this guarantee is not absolute, in the sense that certain confidential information that passes between attorney and client may well not be privileged, ${ }^{1}$ it is vital to the operation of both the client's right to counsel and the lawyer's right to practise his profession. The client must be able to make confidential communications to his or her lawyer and the lawyer must be able to receive such communications from the client, both secure in the knowledge that the contents of these communications are beyond the reach of third parties. ${ }^{2}$

This contribution canvasses the circumstances in which the confidentiality of the attorney-client relationship is vulnerable to breach by a third party. It seeks to determine when a legal practitioner's client records, as the repository of said confidentiality, may be made available to the AML/CFT agencies of the State. The focus is on South Africa, where the issue of warrantless access to the client records of legal practitioners has been the indirect subject of a key Constitutional Court judgment and a subsequent legislative amendment. ${ }^{3}$ To bring a comparative international perspective to bear upon the South African situation, brief reference is made also to how Canada has dealt the matter.

\section{THIRD-PARTY ACCESS TO CLIENT RECORDS}

Third-party access to client records held by legal practitioners is governed by the Financial Intelligence Centre Act 38 of 2001 (FICA). Originally, section 26 of FICA gave an authorised representative of the Financial Intelligence Centre (the Centre) access, during working hours, to any records kept by or on behalf of a legal practitioner. ${ }^{4}$ The representative of the Centre could examine, take extracts from or make copies of any such records, in accordance with the Centre's AML mandate. ${ }^{5}$

Importantly, though, the Centre's access to the records had to be sanctioned by a warrant ${ }^{6}$ issued by a magistrate, regional magistrate or

As a rule, the legal professional privilege protects only confidential attorney-client communications pertaining to legal advice and litigation.

2 See Lewis Legal Ethics: A Guide to Professional Conduct for South African Attorneys (1982) 290.

3 See Estate Agency Affairs Board v Auction Alliance (Pty) Ltd [2014] ZACC 3 and the Financial Intelligence Centre Amendment Act 1 of 2017.

4 See Van der Westhuizen Money Laundering and the Impact Thereof on Selected African Countries: A Comparative Study (LLM thesis, University Pretoria) 2011 38, and Burdette Is the Reporting Obligation of Attorneys in Terms of $S 29$ of the Financial Intelligence Centre Act 38 of 2001 a Myth or Reality? (LLM thesis, University of Pretoria) 201022.

5 S 26(1) of FICA. See also Van der Westhuizen Money Laundering 38 and Burdette Reporting Obligations 22.

6 A warrant was not required in respect of records to which public access existed. 
judge sitting in the jurisdiction where the records were kept or where the attorney practised. ${ }^{7}$ Furthermore, said warrant could be issued only if the presiding judicial officer was satisfied that there were reasonable grounds to believe that the records in question "may assist the Centre to identify the proceeds of unlawful activities or to combat money laundering activities". ${ }^{8} \mathrm{~A}$ warrant could be issued subject to such conditions of access as a designated judicial officer deemed fit, ${ }^{9}$ but a legal practitioner had to give a Centre representative who was armed with a valid warrant all reasonable assistance to examine, excerpt or copy the relevant records. A necessary implication of section 26 of FICA was that a legal practitioner could refuse the Centre access to any records unless its representative was in possession of a valid warrant. ${ }^{10}$

In 2008, FICA was amended, inter alia, by the insertion of sections $45 \mathrm{~A}$ to $45 \mathrm{~F}$. These sections were aimed at monitoring compliance with and enforcement of FICA. To this end, section 45A provided for the appointment of certified inspectors by the Director of the Centre or by the head of a supervisory body which, in the case of law firms, would have been a law society. ${ }^{11}$ Section 45B set out the ambit of FICA compliance inspections. Thus, a FICA inspector could enter and inspect the business premises of any legal practitioner at a reasonable time and after giving said legal practitioner reasonable notice. ${ }^{12}$ Such an inspector could summon a person to appear before him or her for questioning, ${ }^{13}$ and order a person to produce relevant documents ${ }^{14}$ or information pertaining to such documents. ${ }^{15} \mathrm{He}$ or she could also open or order the opening of any strong room, safe or container suspected of holding relevant documents; ${ }^{16}$ retrieve relevant data from any computer system on the premises and reproduce any document from that data $;{ }^{17}$ examine, make extracts from or copy any document in the lawyer's records $;^{18}$ and seize any document which he or she regarded as evidence of non-compliance with FICA. ${ }^{19}$

The powers of the FICA inspectorate to monitor the compliance level of law firms were capacious. These powers were reinforced by the requirement that the legal practitioner provide the inspector with prompt and reasonable assistance to execute an inspection. ${ }^{20}$ The Centre or the law society could

S 26(2) of FICA. See also Burdette Reporting Obligations 22.

S 26(3) of FICA. See also Van der Westhuizen Money Laundering 39.

S 26(4) of FICA.

See also Henning \& Ebersohn "Insider Trading, Money Laundering and Computer Crime" 200133 Transactions of the Centre for Business Law: Combating Economic Crime 125 and Van der Westhuizen Money Laundering 38.

11 The law societies have since been replaced by legal practice councils.

12 S 45B(1) of FICA. See critique hereof in Van der Westhuizen "LSSA Urges Parliament to Respect Professional Legal Confidentiality, Independence of the Profession and the Rule of Law in Amending FICA" 2008 De Rebus 18.

$\mathrm{S} 45 \mathrm{~B}(2)(a)$ of FICA.

$\mathrm{S} 45 \mathrm{~B}(2)(b)$ (i) of FICA.

$\mathrm{S} 45 \mathrm{~B}(2)(b)$ (ii) of FICA

$S 45 \mathrm{~B}(2)(c)$ of FICA.

$S 45 \mathrm{~B}(d)$ of FICA.

$\mathrm{S} 45 \mathrm{~B}(e)$ of FICA

$\mathrm{S} 45 \mathrm{~B}(2)(f)$ of FICA

$S 45 B(3)$ of FICA. 
recover all necessary inspection expenses from the law firm undergoing the inspection. However, an inspector appointed by the Centre could inspect a law firm only if the relevant law society failed to act (or failed to act timeously) upon a recommendation from the Centre to do so. ${ }^{21}$ An inspector appointed by the law society could not conduct a non-routine inspection of a law firm without prior consultation with the Centre. ${ }^{22}$ These latter qualifications did little to circumscribe the broad powers of all FICA inspectors. Then came the jewel in the crown of the FICA inspectorate, which determined that "no warrant is required" for a section 45B inspection. ${ }^{23}$ This had the result that, under the 2008 amendment, a legal practitioner had to allow a FICA inspector warrantless access to his or her client records upon demand.

As pointed out above, section 26 of FICA required that the Centre's access to the records of legal practitioners for AML/CFT purposes be warrant-based. Section 45B(7), by contrast, expressly sanctioned warrantless FICA inspections of such records for compliance purposes. It is evident that section $45 \mathrm{~B}(7)$ contradicts the provisions of section 26. However, the contradiction between the two sections appears to have escaped the attention of the legislature when it inserted section $45 \mathrm{~B}(7)$ into FICA in 2008. It may be arguable that, given the different objectives of the two sections, the contradiction was not as antagonistic as it might seem at first. However, such an argument is hardly sustainable in relation to the overall objectives of the Centre as set out in section 3 of FICA. Be that as it may, the contradiction between section 26 and section 45B was resolved definitively in 2017 by an amendment that deleted both sections from FICA.

Nevertheless, the introduction of warrantless FICA inspections in 2008 was cause for serious concern regarding the expectation of clients as to the confidentiality of the attorney-client relationship. In particular, it raised the spectre of FICA inspectors, whether appointed by the Centre or by a law society, entering the premises of any lawyer and removing any document to be used as evidence against a client or even the lawyer him- or herself at a later stage. In other words, the 2008 amendment made possible the warrantless raiding of a legal practitioner's records to obtain evidentiary ammunition against the legal practitioner and/or his or her clients. Bester's admonition, although offered in relation to the reporting duties imposed on lawyers by FICA, rings true in this context as well:

"Certainly, and at its lowest ebb, the mere notion of 'conscription' of attorneys to 'spy' on and report on the doings of their unsuspecting clients to a government agency and to be designated the repository of the clients rights, no matter how noble the cause, is morally and ethically repugnant." ${ }^{2}$

$\mathrm{S} 45 \mathrm{~B}(6)(a)$ of FICA.

$\mathrm{S} 45 \mathrm{~B}(6)(b)$ of FICA.

S 45B(7) of FICA.

24 Bester "An Assault on the Attorney-Client Relationship and on the Independence of the Profession?" 2002 De Rebus 29. See also Millard \& Vergano "Hung Out To Dry? AttorneyClient Confidentiality and the Reporting Duties Imposed by the Financial Intelligence Centre Act 38 of 2001" 2013 Obiter 409; Burdette Reporting Obligations 34; and Klaff "Fica is Unconstitutional" 2004 De Rebus 5. 
The next section discusses the case of Estate Agency Affairs Board $v$ Auction Alliance ${ }^{25}$ which considered the constitutionality of section $45 \mathrm{~B}$ of FICA.

\section{ESTATE AGENCY AFFAIRS BOARD V AUCTION ALLIANCE (PTY) LTD}

This case concerns the real estate sector and so does not deal directly with the client records of legal practitioners. However, it does deal directly with the section of FICA that (at that time) governed access to such records. ${ }^{26}$ It is thus of cardinal significance to the question of the confidentiality of legal practitioners' client records. The matter originated in the Western Cape High Court when Auction Alliance, an estate agency, opposed an attempt by the Estate Agency Affairs Board to conduct a warrantless search of its offices. The High Court declared both section 32A of the Estate Agency Affairs Act and section 45B of FICA unconstitutional. Both these sections conferred wide powers of warrantless search and seizure upon regulatory bodies. ${ }^{27}$ The matter went to the Constitutional Court for confirmation of the High Court order.

The litigation occurred against the following factual backdrop. Rael Levitt was the founder and former head of Auction Alliance. In 2012, a television programme about Levitt was aired. It was alleged that Auction Alliance was guilty of a host of serious contraventions of both the Estate Agency Affairs Act and FICA. ${ }^{28}$ The producers of the television programme provided the Estate Agency Affairs Board with the material on which the allegations were founded. The Board launched an investigation into the matter in collaboration with the Centre. While the Board and the Centre were planning the way forward, it emerged that Auction Alliance was disposing of potentially inculpatory evidence. The Board responded by ordering urgent inspections of Auction Alliance's offices in Cape Town, Johannesburg and Durban. These were non-routine inspections, ${ }^{29}$ in the sense that they were unannounced and warrantless. ${ }^{30}$ However, Auction Alliance denied the Board's inspectors access to its offices. What is more, it approached the Western Cape High Court with an application - first, to veto warrantless

\footnotetext{
Supra.

Estate Agency Affairs Board v Auction Alliance (Pty) Ltd supra par 65.

Auction Alliance (Pty) Ltd v Estate Agency Affairs Board [2013] ZAWCHC 105 par 27 and 55.

28 MyProperty "Rael Levitt Steps Down as CEO of Auction Alliance \& Investec Responds to Accusations" (28 February 2012) https://www.myproperty.co.za/news/rael-levitt-steps-downas-ceo-of-auction-alliance-and-investec-responds-to-accusations-28-02-12 (accessed 201901-09).

29 In Auction Alliance (Pty) Ltd v Estate Agency Affairs Board supra par 55, the High Court defined a non-routine inspection as "an inspection which an inspector has decided to conduct because a suspicion exists that a failure to comply with this Act or any order, determination or directive made in terms of this Act or that a contravention of the Act has occurred and because the inspector suspects that information pertaining to such failure or contravention may be discovered if the premises in question are subjected to an inspection". It defined a routine inspection negatively, as one "other than a non-routine inspection".

30 Estate Agency Affairs Board v Auction Alliance supra par 8.
} 
inspections by the Board and, secondly, to declare unconstitutional section $32 \mathrm{~A}$ of the Estate Agency Affairs Act and section 45B of FICA, at least with regard to non-routine inspections. ${ }^{31}$

The first aspect of the application was resolved extra-curially when Auction Alliance and the Board agreed that KPMG, an accounting firm, would become the custodian of all the former's computer data. The High Court only had to decide upon the constitutionality of the two statutory provisions that Auction Alliance alleged were unconstitutional. In this regard, the court held that section 32A of the Estate Agency Affairs Act was indeed unconstitutional, ${ }^{32}$ adding that the section could not be rescued either by a reading-down or a reading-in ${ }^{33}$ The High Court also declared section $45 \mathrm{~B}$ of FICA to be unconstitutional. ${ }^{34}$ However, it suspended its declaration for 18 months in order to allow the legislature the chance to enact an appropriate amendment. However, the court undertook "an extensive reading in", ${ }^{35}$ which essentially required a warrant for non-routine inspections during the period of suspension.

The Constitutional Court had little hesitation in confirming the High Court's declarations of constitutional invalidity for both section 32A of the Estate Agency Affairs Act and section 45B of FICA. It held that these two sections went too far by authorising warrantless searches across the board, regardless of the nature of the search or the premises targeted. Hence the sections failed "to pass constitutional scrutiny". ${ }^{36}$ For legal practitioners, section 45B of FICA was the provision that mattered because it authorised warrantless inspections of their offices. In this connection, the Constitutional Court observed that even the AML/CFT objectives of FICA could not justify the unconstrained warrantless searches authorised by the section. ${ }^{37}$

The Constitutional Court then went further, suspending the invalidity of both section 32A of the Estate Agency Affairs Act and section 45B of FICA for a period of 24 months in order to allow the legislature time to enact the amendments needed for the statutes to pass constitutional muster. The order made by the Constitutional Court included an extensive

31 Estate Agency Affairs Board v Auction Alliance supra par 9.

32 The High Court considered that the section was overbroad in its liberal authorisation of warrantless inspections and that such inspections could not be justified under the limitations clause of the Constitution.

33 Estate Agency Affairs Board v Auction Alliance supra par 16.

34 The High Court found that the section was not overbroad because it prescribed a number of conditions for warrantless inspections. Nevertheless, it declared the section unconstitutional because it considered that the non-routine inspections should be warrant-based.

Estate Agency Affairs Board v Auction Alliance supra par 20.

36 Estate Agency Affairs Board v Auction Alliance supra par 40.

37 Estate Agency Affairs Board v Auction Alliance supra par 42-43. 
reading-in for section $45 \mathrm{~B}$ of FICA to cover the period of suspension. ${ }^{38}$ The reading-in began by excluding private residences as business premises, which, in terms of section 45B(1), FICA inspectors could enter and search to assess compliance with FICA. It bears noting here that the Constitutional Court did not require that such compliance inspections be authorised by a warrant, and thus did not depart in any material way from section $45 \mathrm{~B}(1)$ as enacted in 2008.

The rest of the reading-in comprises section $45 \mathrm{~B}(1 \mathrm{~A})$, which put an end to carte blanche warrantless compliance inspections. First, the Constitutional Court required a warrant, issued by a judge or magistrate, in two cases: for every search based on suspicion of criminal conduct by its target; and for every search of a private residence. ${ }^{39}$ Secondly, the FICA inspector had to apply for the warrant on affidavit, explaining why the search was necessary. ${ }^{40}$ Thirdly, the judicial officer could issue the warrant only if there were reasonable grounds to suspect that FICA had been contravened, if the search was likely to confirm the contravention, and if the search was reasonably necessary in relation to the purposes of FICA. ${ }^{41}$ Collectively, these three parts of the reading-in constitute a prescription that FICA inspections in the designated instances be warrant-based, and nullify the original and wide no-warrant spirit of section $45 \mathrm{~B}(7)$.

38 Paragraph 6 of the order is dedicated to section 45B of FICA. It says:

"During the period of suspension, section $45 \mathrm{~B}(1)$ of the Financial Intelligence Centre Act is deemed to read as follows, what is underlined being the reading in:

(1) For the purposes of determining compliance with this Act or any order, determination or directive made in terms of this Act, an inspector may at any reasonable time and on reasonable notice, where appropriate, enter and inspect any premises, except a private residence, at which the Centre or, when acting in terms of section $45(1)$, the supervisory body reasonably believes that the business of an accountable institution, reporting institution or other person to whom the provisions of this Act apply, is conducted. (1A)

(a) Where the Centre or a supervisory body acting after consultation with the Centre suspects that a criminal offence has been or is being committed by the person who is the subject of the search, or where it seeks to search premises that are a private residence, an inspector in terms of subsection (1) may conduct a search only on the authority of a warrant issued by a magistrate or judge.

(b) A magistrate or judge may issue a warrant only on written application by an inspector setting out under oath or affirmation the grounds why it is necessary for an inspector to gain access to the relevant premises.

(c) The magistrate or judge may issue the warrant if it appears from information on oath or affirmation that-

(i) there are reasonable grounds for suspecting that a contravention of the Act has occurred;

(ii) a search of the premises is likely to yield information pertaining to the contravention: and

(iii) the search is reasonably necessary for the purposes of the Act.

(d) An inspector otherwise required to obtain a warrant under paragraph (a) may enter and search any place without the warrant referred to in paragraph (c) if the inspector on reasonable grounds believes that-

(i) a warrant would be issued in terms of paragraph (c) if the inspector applied for it; and

(ii) the delay in obtaining the warrant is likely to defeat the object of the search."

$9 \mathrm{~S} 45 \mathrm{~B}(1 \mathrm{~A})(\mathrm{a})$ of the reading-in.

$40 S 45 B(1 A)(b)$ of the reading-in.

$41 \mathrm{~S} 45 \mathrm{~B}(1 \mathrm{~A})(c)$ of the reading-in. 
Significantly, though, the Constitutional Court did not rule out warrantless inspections completely. First, the court did not require that routine compliance inspections, conducted in terms of section $45 \mathrm{~B}(1)$, be warrantbased. Secondly, whereas section $45(1 \mathrm{~A})(a)-(c)$ of the reading-in prescribed warrants in two exceptional cases, section $45(1 \mathrm{~A})(d)$ contemplates the possibility of exceptions to these exceptions. According to the Constitutional Court, warrantless inspections would be allowed in urgent circumstances, specifically if the FICA inspector has a reasonable belief that his or her application for the required warrant would have been granted but that the accompanying delay would have subverted the purpose of the inspection. During the 24-month period of suspension, inspections of private premises and inspections prompted by suspected criminality had to be warrant-based (subject to an urgency proviso), while warrantless inspections in routine cases survived. ${ }^{42}$

\section{FINANCIAL INTELLIGENCE CENTRE AMENDMENT ACT 1 OF 2017}

The declaration of constitutional invalidity was issued in February 2014. The amendment intended to address the constitutional invalidity of section 45B of FICA was enacted in May 2017 as the part of the Financial Intelligence Centre Amendment Act 1 of 2017.

An obvious highlight of the amendment is the deletion of section $45 \mathrm{~B}(7)$, which expressly allowed warrantless compliance inspections. In addition, the amendment appears to incorporate the bulk of the reading-in provided by the Constitutional Court in Estate Agency Affairs Board $v$ Auction Alliance ${ }^{43}$ for the period of suspension. Thus, section $45 \mathrm{~B}(1)(b)$ of FICA now excludes private residences from the general purview of premises subject to compliance inspections. However, as with the Constitutional Court's readingin, the amendment does not prescribe a warrant for such inspections. If compliance inspections are mostly routine, then it would seem that warrantless inspections will continue to be the order of the day, despite the deletion of section $45 \mathrm{~B}(7)$.

A warrant requirement does appear in the new section $45 \mathrm{~B}(1 \mathrm{~A})$ of FICA. It stipulates that a warrant is needed for any compliance inspection of a private residence and of unlicensed business premise ${ }^{44}$ reasonably believed to be the site of a business to which FICA applies. Again, this aspect of the 2017 amendment does not depart substantively from the reading-in undertaken by the Constitutional Court. The amendment also identifies two cases that fall

42 When the High Court declared s 45B of FICA unconstitutional, it also suspended the invalidity, but for a period of 18 months. It also provided a reading-in for the period of suspension, which declared explicitly: "No warrant is required for the purposes of a routine inspection." See Auction Alliance v Estate Agency Affairs Board supra par 55.

43 Supra

44 It would seem that unlicensed business premises are any premises that are not a private residence and not regular business premises. Both the references to private residences and unlicensed business premises appear to be aimed, in the case of legal practitioners, at those who practise from premises that fall outside the conventional notion of registered law offices. 
outside the ambit of the new section $45 \mathrm{~B}(1)$ and for which a compliance inspection must be warrant-based.

The new section $45 \mathrm{~B}(1 \mathrm{~B})$ sets out the conditions for the issue of the warrant prescribed under section $45 \mathrm{~B}(1 \mathrm{~A})$. First, the inspectorate must apply to a magistrate or judge on affidavit, justifying the necessity for the inspection. ${ }^{45}$ Secondly, the application must convince the judicial officer that there is a reasonable suspicion of non-compliance, that the inspection is likely to produce evidence of said non-compliance, and that the inspection is reasonably necessary to determine compliance with FICA. ${ }^{46}$ Again, these conditions are not significantly different from those prescribed by the Constitutional Court. The legislature appears to have replicated, for the most part, the reading-in of the Constitutional Court as regards both the circumstances in which a compliance inspection requires a warrant and the conditions that have to be met for the warrant to be issued.

Section $45 \mathrm{~B}(1 \mathrm{C})$ of the 2017 amendment continues the legislature's conformity to the judgment of the Constitutional Court by also providing for possible exceptions to the warrant requirement for compliance inspections of private residences and unlicensed business premises. Warrantless inspections of such premises are permitted in two instances. The first is by consent. Here it depends on whether the inspection is of a private residence or unlicensed business premises. For a private residence, the consent of both the person running the business conducted there and of the person occupying the specific area to be inspected must be given. In both cases, the person giving the consent must have been advised by the FICA inspectorate that he or she has no legal obligation to allow a warrantless inspection. ${ }^{47}$ The second possible exception is one authorised by the Director of the Centre or the head of a legal practice council (LPC). A warrantless inspection of a private residence or unlicensed business premises may be permitted by either official if he or she has a reasonable belief that a warrant application would succeed, the delay occasioned by an application would subvert the purpose of the inspection, and the inspection is necessary to implement the compliance competencies of inspectors as set out in section $45 \mathrm{~B}(2){ }^{48}$

This second possible exception accords, more or less, with the Constitutional Court's urgency proviso, referred to above, allowing for warrantless inspections as exceptions to the cases that normally would require a warrant. That is sensible, as illustrated by the destruction or attempted destruction of evidence as reported in Estate Agency Affairs Board $v$ Auction Alliance. ${ }^{49}$ In any event, it could hardly be expected that the legislature would enact a provision that is absolute in its prescription of a warrant. In the case of economic crime, speed often is the factor upon which the success or failure of a search or an inspection turns. The process of applying for and acquiring a warrant can be time-consuming and could jeopardise the AML/CFT efforts of law enforcement agencies. Where the

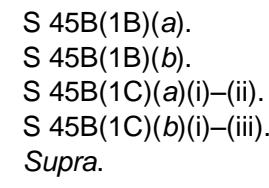


urgency is real, then, the exceptional warrantless inspection is probably unassailable. What is more, although it allows warrantless inspections, the amendment does so outside of the warrantless ethos of the 2008 FICA amendment.

The first possible exception, which contemplates consent-based warrantless inspections, did not feature in the reading-in undertaken by the Constitutional Court in Estate Agency Affairs Board v Auction Alliance. ${ }^{50}$ It also was not an aspect of any of the previous versions of FICA, including the amendment of 2008, which was quite indulgent towards the FICA authorities. It is a novel provision, which constitutes part of the legislative response to the invalidation of section $45 \mathrm{~B}$ by the Constitutional Court. However, the introduction of the notion of consent-based warrantless inspections in an amendment aimed at restoring the constitutionality of section 45B ought to be worrying to any legal practitioner.

It is a truism that consent by a person to conduct that is prejudicial or potentially prejudicial to his or her legal interests must be informed consent. In other words, the consent ought to be given freely and voluntarily with an ample appreciation of the meaning and consequences of the conduct in question. The problem with the consent exception in the 2017 FICA amendment is that it applies to inspections of non-conventional premises and the persons in control of or occupying such premises might not be in a position to give informed consent. For example, both "the person apparently in control of the business reasonably believed to be conducted at the private residence" ${ }^{\prime 1}$ and "the occupant of the part of the private residence to be entered and inspected"52 may be lay people who, in the face of the palpable clout of the FICA inspectorate, may be persuaded to consent to a warrantless search of a private residence without a proper comprehension of the implications of such consent. Mere knowledge that they are not obliged to consent is not sufficient to render their consent informed; as often the formidable facticity of state authority and its accoutrements may negate any notion of resistance. Much the same may be said of consent to a warrantless inspection of unlicensed business premises given by "the person apparently in control of the business reasonably believed to be conducted at the premises". ${ }^{53}$ Such business may be conducted, for instance, from the back of a truck or from a room in a motel and managed by a lay administrator. Again, the chances of said person being coaxed into providing consent, despite being informed that it is not obligatory to do so, are overwhelming. The point is that, in the case of private residences and unlicensed business premises, the power differential (between FICA inspectors and the persons invested with competence to consent) is likely to tip the scales in favour of the former.

The legislature's resort to consent-based warrantless inspections is perplexing. It is quite unnecessary and smacks of legislative expediency to introduce a new form of warrantless inspection into a section of FICA that had fallen foul of the Constitution, not least because of its open embrace of

\footnotetext{
Supra.

$\mathrm{S} 45 \mathrm{~B}(1 \mathrm{C})(\mathrm{a})(\mathrm{i})(\mathrm{aa})$

$S 45 B(1 C)(a)(i)(b b)$

$\mathrm{S} 45 \mathrm{~B}(1 \mathrm{C})(\mathrm{a})(\mathrm{ii})$.
} 
warrantless inspections. Furthermore, the idea of consent is constrained always by the risk of its not being informed. The amendment pays no attention to this problem, and merely requires that the person consenting be advised by the FICA inspectorate that he or she is not required to allow a warrantless inspection. Needless to say, there is a world of difference between being informed that one may withhold consent and giving informed consent. Finally, the possibility of consent-based warrantless inspections carries with it the inevitability of legal challenges based on the quality of the consent. The brouhaha that will ensue, for example, after a legal secretary consents to a warrantless compliance inspection of a legal practitioner's unlicensed business premises is foreseeable. The legislature in fact is inviting the kind of legal protests and confrontations that, presumably, the amendment to FICA was meant to avert.

\section{THIRD-PARTY ACCESS TO CLIENT RECORDS REVISITED}

The question now arises as to what the 2017 amendment of FICA means for third party access to the client records of legal practitioners in South Africa. The invalidation of section 45B of FICA by the Constitutional Court in Estate Agency Affairs Board $v$ Auction Alliance ${ }^{54}$ may have engendered some optimism that the legislature would put an end to warrantless inspections of law practices. However, such optimism would have been misplaced as the legislature appears to have embraced the reading-in undertaken by the Constitutional Court as the benchmark for its response to the constitutional voiding of section 45B of FICA. The 2017 FICA amendment, for all intents and purposes, enacted the major elements of the 2014 Constitutional Court reading-in.

Significantly, the 2014 reading-in did not outlaw all warrantless inspections, and even made provision for them in certain circumstances. Indeed, as seen earlier, the Constitutional Court required that inspections be warrant-based only in two non-routine cases. ${ }^{55}$ For the rest, FICA compliance inspections could be warrantless. In effect, the Constitutional Court upheld the general rule of warrantless inspections introduced by the 2008 FICA amendment and approved warrant-based inspections only as exceptions to the rule. ${ }^{56}$ The 2017 FICA amendment endorses warrantless routine inspections as standard. Warrants are necessary only for specific non-routine inspections, and even then they may be conducted without a warrant in urgent and consensual cases. The exception of the consensual warrantless inspection is the only material legislative deviation from the 2014 Constitutional Court reading-in. As suggested above, it is also the provision of the 2017 FICA amendment likely to be most troublesome for all parties.

\footnotetext{
Supra.

55 These were: a suspected crime by the target of a search; and searches of private residences.

56 The court may well have done so because Auction Alliance had restricted its constitutional challenge to warrantless non-routine inspections. Nonetheless, the reading-in was bad news overall for legal practitioners in the sense that their client records remained, for the most part, fully accessible to the FICA inspectorate without a warrant.
} 
The key feature of the 2017 FICA amendment is that it legislates for warrantless access by the FICA inspectorate to the client records of legal practitioners as a norm. The warrant-based inspection continues only as a peculiarity. This approach leaves vulnerable the legal professional privilege and the principle of confidentiality governing the attorney-client relationship. If nothing else, the 2017 FICA amendment ought to be a red flag for all legal practitioners, and especially those who have clients alleged to be money launderers.

The notion of warrantless FICA inspections of law practices as a norm needs to be emphasised. It was introduced into FICA in 2008 via section 45B(7); condoned by the Constitutional Court in 2014 in Estate Agency Affairs Board v Auction Alliance; and re-enacted in the 2017 FICA amendment. The point is that, since 2008, the offices of South African legal practitioners have been accessible to search and their records available for seizure by FICA inspectors, in most cases without a warrant. Estate Agency Affairs Board $v$ Auction Alliance caused a right stir at the time, especially as regards the striking-down of section 45B of FICA. However, the decision of the Constitutional Court did nothing to protect the legal professional privilege. Instead, its reading-in more or less regularised the warrantless inspection as the criterion of FICA compliance. Certainly, legal practitioners could take little comfort from the reading-in. It placed confidential client information at the unencumbered disposal of the FICA inspectorate and, by extension, the criminal justice authorities. What appeared to be a progressive Constitutional Court ruling on non-routine inspections harboured a quite serious incursion into the attorney-client relationship as far as routine inspections go. Unsurprisingly, that incursion, allowed by the Constitutional Court, was entrenched in the 2017 FICA amendment.

From the legal practitioner's perspective, warrantless access by FICA inspectors to confidential client information is cause for grave concern. The problem is that it carries the approval of the Constitutional Court, more or less. The organised legal profession, as a supervisory body, has been noticeably silent on the matter. This may be ascribed to the fact that the LPC forms part of the FICA inspectorate and hence, along with the Centre, is one of the beneficiaries of the 2017 amendment. Whatever the reason, South African legal practitioners have now to contend with the idea of having the details of their clients' dealings becoming known to a third party at the behest of that party alone. It is a schema that fits well into the overall AML/CFT objectives of FICA. However, it jeopardises the core notion of legal professional privilege upon which pivots the integrity of all legal practice. The competence of the Centre and of the LPC to conduct warrantless compliance inspections may yield the kind of information and knowledge required by the National Prosecuting Authority to institute criminal proceedings against clients of legal practitioners and even against the legal practitioners themselves. It transforms the offices of legal practitioners into evidentiary resources for the AML/CFT agencies of the State.

The 2017 FICA amendment was enacted during the latter years of Jacob Zuma's presidency. Interestingly, in November 2016, some six months after the National Assembly had adopted the amendment Bill, Zuma invoked 
section 79(1) of the Constitution to refer the Bill back to the National Assembly on the grounds that he had reservations about the constitutionality of section $45 \mathrm{~B}(1 \mathrm{C})$ - in particular, its provisions allowing for warrantless inspections. ${ }^{57}$ Zuma's concerns were suspected to be politically motivated and were negated by weighty legal opinion declaring that section $45 \mathrm{~B}(1 \mathrm{C})$ passed the test of constitutionality. ${ }^{58}$ There was a public clamour for the Bill to be passed and Zuma signed it into law in April 2017. ${ }^{59}$ Jacob Zuma's reduced reputation and circumstances notwithstanding, his invocation of section 79(1) of the Constitution highlighted an issue that elicited little if any comment elsewhere. Whatever his motives for raising it, the question of whether section $45 \mathrm{~B}(1 \mathrm{C})$ of the amendment Bill violated the right to privacy protected in section 14 of the Constitution was a valid one.

Significantly though, Zuma was concerned only with the exceptions to those cases in which a warrant was required for inspections. In other words, he objected only to warrantless inspections of private residences and of unlicensed business premises. He had nothing to say about inspections of premises that were neither private residences nor unlicensed business premises, and hence would not require a warrant. He did not want nonroutine inspections to be warrantless but did not take issue with routine inspections being so. However, if, as is the case, most legal practitioners operate from premises that are not private residences or unlicensed business premises, then compliance inspections of their practices would be governed by section $45 \mathrm{~B}(1)$ of the 2017 FICA amendment. The necessary implication is that the bulk of inspections of law practices will be warrantless.

Most South African legal practitioners will be required by law to give the FICA inspectorate more or less unfettered access to their client records as and when compliance inspections are conducted. The consequences for clients, attorneys and the attorney-client relationship can be serious. When a legal practitioner is required to make available client particulars and transactions to a third party in the absence of a warrant, the precious

57 See The Presidency "President Zuma Refers FICA Amendment Bill to the National Assembly" (26 November 2016) http://www.thepresidency.gov.za/pressstatements/president-zuma-refers-fica-amendment-bill-national-assembly (accessed 201901-09); BusinessTech "New FICA Bill Allows the Search of Prominent Individuals' Finances Without a Warrant - Here's Who's For and Against It" (25 January 2017) https://businesstech.co.za/news/finance/152595/new-fica-bill-allows-the-search-ofprominent-individuals-finances-without-a-warrant-heres-whos-for-and-against-it/ (accessed 2019-01-09).

58 These included a formal legal opinion commissioned by the Banking Association of South Africa. See Marcus \& Stubbs "The Constitutionality of Warrantless Searches: A Case that Requires Reinvention" (18 January 2017) https://www.banking.org.za/docs/defaultsource/presentations/2016-12-14-opinion-basa-re-constitutionality-warrantlesssearches.pdf?sfvrsn=2 (accessed 2019-01-09).

59 See Pather "Crib Notes: Everything You Need to Know about the FIC Amendment Bill" Mail \& Guardian (31 January 2017) https://mg.co.za/article/2017-01-31-crib-notes-everythingyou-need-to-know-about-the-fic-amendment-bill (accessed 2019-01-09); eNCA "FICA Bill Amendments Clarified" (21 February 2017) https://www.enca.com/south-africa/fica-billamendments-clarified (accesed 2019-01-09); Pijoos "President Zuma Signs FICA Bill into Law" Mail \& Guardian (29 April 2017) https://mg.co.za/article/2017-04-29-president-zumasigns-fica-bill-into-law (accessed 2019-01-09); Booysen "FICA Amended - Needs Implementation" Brief (6 June 2017) https://www.bbrief.co.za/2017/06/06/fica-amendedneeds-implementation/ (accessed 2019-01-09). 
principle of legal professional privilege is in peril. As intimated above, warrantless inspections are defensible, even necessary, in certain exceptional cases. However, they have no place outside such cases and certainly should not be common-place. Yet, that is exactly what the legislature has done. It has transformed the warrantless inspection from the exception to the rule. This is the caveat jurisconsultus - the real danger for lawyers lurking in the 2017 FICA amendment: that their records could become repositories of prosecutorial ammunition against their clients. Strikingly, in Estate Agency Affairs Board $v$ Auction Alliance, the Constitutional Court appeared to condone this possibility. Its primary concern was that the old section 45B should in principle allow all inspections to be warrantless; it did not seem to be troubled that in practice most inspections were warrantless. Indeed, the Constitutional Court allowed for this practice to continue by leaving the old section $45 \mathrm{~B}(1)$ virtually intact when it undertook its reading-in exercise. Unsurprisingly, therefore, the legislature re-enacted the warrantless inspection as the norm and, ironically, it did so while the pundits were debating warrantless inspections as the exception.

\section{A CANADIAN EXCURSUS}

The gravity of the situation facing South African lawyers is brought into sharp relief when reference is had to the position of their Canadian counterparts. The latter, quite simply, have no obligation whatsoever to grant Canada's financial intelligence unit, known as the Financial Transactions and Reports Analysis Centre (FINTRAC), access to their client records. In this connection, the Supreme Court of Canada has pronounced that the confidentiality inscribed in the attorney-client relationship is fundamental to both "the functioning of the criminal justice system and to the protection of the constitutional rights of accused persons", and that the offices of legal practitioners ought not to become "archives for the use of the prosecution". ${ }^{60}$

This declaration expresses well the respect and protection that Canadian law affords the legal professional privilege. In that country, the integrity of the attorney-client relationship takes precedence over the State's interest in combating economic crime. This state of affairs is due in no small part to the activism of the legal profession, as represented by the Federation of Law Societies of Canada (FLSC).

Canada's primary AML statute is the Proceeds of Crime (Money Laundering) and Terrorist Financing Act (PCMLTFA), which was enacted in 2000. Sections 62,63 and 63.1 of the PCMLTFA contain compliance measures that are not too dissimilar from FICA's: warrantless access for FINTRAC is the norm, whereas entry into a dwelling house requires a warrant (unless the occupant consents). However, unlike FICA, section 64 of the PCMLTFA allowed a legal practitioner to exclude certain documents of clients or former clients from a FINTRAC inspection by asserting attorneyclient privilege on behalf of the client or former client in respect of those documents. What is more, almost from the commencement of the

60 Maranda v Richer [2003] 3 SCR 193, 2003 SCC 67 par 37. 
PCMLTFA, the FLSC conducted a sustained campaign in the Canadian courts against the compliance measures insofar as they affected its members. ${ }^{61}$ The litigation, which was aimed, inter alia, at exempting legal practitioners from the reach of these measures, began with injunction proceedings in 2001; it then went to the Supreme Court of British Columbia in 2011, and thereafter to the British Columbia Court of Appeal in 2013. ${ }^{62}$ Matters were settled finally by the Supreme Court of Canada in the 2015 case of Attorney General of Canada v Federation of Law Societies of Canada. ${ }^{63}$

According to the Supreme Court, the warrantless searches that the PCMLTFA allowed were "presumptively unreasonable" 64 and the protection that section 64 purported to give the attorney-client relationship was inadequate. ${ }^{65}$ The court found that sections $62,63,63.1$ and 64 collectively constituted "a very significant limitation of the right to be free of unreasonable searches and seizures guaranteed by section 8 of the Charter"66 and that the limitation was not justifiable in relation to legal practitioners. ${ }^{67}$ On this basis, the Supreme Court invalidated section 64 and found that sections 62,63 and 63.1 should be read down to exclude documents in the possession or at the premises of legal practitioners. ${ }^{68}$ After some 15 years of litigation, the FLSC had prevailed: its members were beyond the remit of the compliance measures of the PCMLTFA.

In Attorney General of Canada v Federation of Law Societies of Canada, the Supreme Court of Canada was unequivocal that "the state cannot impose duties on lawyers that interfere with their duty of commitment to advancing their clients' legitimate interests" ${ }^{69}$ It went on to declare that the PCMLTFA infringes materially upon said duty of commitment by requiring legal practitioners to act as "state agents" against the legitimate interests of their clients. ${ }^{70}$

The judgment affirms the centrality of attorney-client confidentiality not only to the criminal justice system but also to the legal system as a whole. In this connection, the court held that the administration of justice requires that clients enjoy absolute confidence in their lawyers, that legal practitioners be committed to the cause of their clients and that they protect all client

61 See Terry "An Introduction to the Financial Action Task Force and Its 2008 Lawyer Guidance" 2010 Journal of the Professional Lawyer 3 \& 34; Paton "Cooperation, Co-option or Coercion? The FATF Lawyer Guidance and the Regulation of the Legal Profession" 2010 Journal of the Professional Lawyer 171; Macdonald "Money Laundering Regulation: What Can Be Learned From the Canadian Experience?" 2010 Journal of the Professional Lawyer 144; and Gallant "Uncertainties Collide: Lawyers and Money Laundering, Terrorist Financing Regulations" 2009 16(3) Journal of Economic Crimes 211.

62 Law Society of British Columbia v Canada 2001 (BCSC) 1593; Federation of Law Societies of Canada $v$ Canada 2011 (BCSC) 1270 and Federation of Law Societies of Canada $v$ Canada 2013 (BCCA) 147.

632015 SCC 7.

64 Attorney General of Canada v Federation of Law Societies of Canada supra par 56.

65 Attorney General of Canada v Federation of Law Societies of Canada supra par 57.

6 Ibid.

Attorney General of Canada v Federation of Law Societies of Canada supra par 62.

Attorney General of Canada v Federation of Law Societies of Canada supra par 67.

Attorney General of Canada v Federation of Law Societies of Canada supra par 77.

70 Ibid. 
confidences. ${ }^{71}$ Unlike the Canadian legislature, the Supreme Court accorded the legal professional privilege its proper place in the matrix of legal relations. And in so doing, it reclaimed the inviolability of the attorney-client relationship against government intrusion.

The judgment in Attorney General of Canada $v$ Federation of Law Societies of Canada represented a major victory for Canadian legal practitioners and ought to be savoured as such. It has been settled definitively that the legal profession is exempt from the compliance provisions of the PCMLTFA; and that the client records of legal practitioners are not storehouses from which the State may extract intelligence for the prosecutorial cause under the guise of a FINTRAC inspection. In Canada, then, third parties have no access to the records of legal practitioners without a warrant duly authorised by a competent court.

\section{CONCLUSION}

In both Canada and South Africa, the AML/CFT legislation allows the financial intelligence unit of each country access to the records of legal practitioners for compliance purposes. Indeed, the compliance provisions of the two countries are comparable, more or less. Yet South African legal practitioners are in an incomparably worse position than their Canadian counterparts when it comes to their records being raided for inculpatory evidence against their clients. On the one hand, such intrusion by the State is no longer possible in Canada - essentially because the FLSC fought against it with gritty determination for a long time and the Supreme Court eventually ruled that legal practitioners were not subject to the compliance provisions of the PCMLTFA. On the other hand, it continues to be possible in South Africa, primarily because the organised profession did not put up a fight and the Constitutional Court did not see fit to protect the records of legal practitioners from state incursion in the form of compliance inspections. Whereas the records of Canadian legal practitioners are available to third parties such as FINTRAC only by way of a warrant, those of South African legal practitioners are subject to warrantless FICA inspections as a matter of course.

The legal professional privilege and attorney-client confidentiality are pillars of legal practice, and it is incomprehensible that the offices of legal practitioners should be raided by state agents to acquire evidence against their clients without a duly authorised warrant. Unfortunately, this was precisely the effect that the Canadian and South African AML/CFT statutes envisaged. The offending provisions have been invalidated in Canada but they persist in South Africa. The 2017 FICA amendment was enacted after the judgment in Attorney General of Canada v Federation of Law Societies of Canada. The Canadian developments clearly had no impact on the South African legislature. South African legal practitioners must continue to practise their craft in the knowledge that their records continue as caches of information that could be turned against their clients in criminal prosecutions.

${ }^{71}$ Attorney General of Canada v Federation of Law Societies of Canada supra par 83. 
It is a burden that is surely "presumptively unreasonable" and which no legal practitioner can be expected to bear with equanimity.

In 2002, Bester had anticipated, albeit for a different aspect of FICA, that the legal profession would have "to challenge the constitutionality of the legislation or to seek an exemption from its operation". ${ }^{72}$ Seventeen years later, there can be no doubt that Bester's foresight has become an imperative for the South African LPC as regards the 2017 FICA amendment.

72 Bester 2002 De Rebus 25. 